\title{
14-3-3 Protein Sigma
}

National Cancer Institute

\section{Source}

National Cancer Institute. 14-3-3 Protein Sigma. NCI Thesaurus. Code C26474.

14-3-3 protein sigma ( $248 \mathrm{aa}, \sim 28 \mathrm{kDa}$ ) is encoded by the human SFN gene. This protein plays a role in adaptor signal protein functions. 